\title{
Dispersed Collections of Scientific Books: The Case of the Private Library of Federico Cesi $\left(15^{8} 5^{-1630}\right)$
}

\author{
Maria Teresa Biagetti
}

The extraordinary library collected by Federico Cesi, founder in 1603 of the Accademia dei Lincei in Rome, is a clear manifestation of the scientific personality of its owner. In the scientific community of the early seventeenth century, Federico Cesi occupies a prominent position in both the fields of botany and zoology. However, botany was his principal love. In this field, while dutifully acknowledging the authority of Pliny and Theophrastus, he confidently proposed himself as successor of Pietro Andrea Mattioli and Andrea Cesalpino. ${ }^{1}$ He was interested in the subfield constituted by the scientific researches of Ulisse Aldrovandi and Giambattista Della Porta, Gaspar Bauhin, Jacobus Theodorus and Matthias de L'Obel. ${ }^{2}$ His investigations of the reproduction of the plants, which were never published, were innovative; ${ }^{3}$ particularly relevant to the field of botany is his planned encyclopedia synthesized in the Tabulae Phytosophicae, which reveals his taste for schematic organization through the creation of tables and diagrams. ${ }^{4}$ The desire to analyze the minute details of plants is confirmed by the presence of detailed drawings of plants, flowers and mushrooms in some manuscripts that formed part of his library, now in the

1 Pietro Andrea Mattioli (1500-1577), physician and naturalist, born in Siena. Andrea Cesalpino (c. 1524-1603), physician, botanist, and professor of Medicine at the Sapienza University of Rome.

2 Ulisse Aldrovandi (1522-1605), physician and naturalist from Bologna. Giambattista Della Porta (c. 1540-1615), naturalist, scholar and polymath from Napoli. Jacobus Theodorus Tabernaemontanus (1522-1590), German botanist and physician. The Flemish Matthias de L'Obel (1538-1616), had been physician of William I, Prince of Orange, and physician and botanist of James I, King of England.

3 Antonio Graniti, Il mondo vegetale nella visione di Federico Cesi, in Antonio Graniti (ed.), Federico Cesi: un principe naturalista (Roma: Bardi, 2006), pp. 18-99.

4 Tabulae Phytosophicae, published as an appendix to Nova plantarum, animalium et mineralium mexicanorum historia a Francisco Hernandez ... Cui demum accessere aliquot ex principis Federici Ceesii Frontispiciis Theatri naturalis Phytosophicce Tabulce ... (Romae, Typis Vitalis Mascardi, 1651), pp. 901-950). 
Bibliothèque de l'Institut de France at Paris. ${ }^{5}$ The focus on iconographic documentation probably derived from knowledge of the method adopted by Aldrovandi in the sixteenth century, namely the use of detailed depictions of animals and plants created by engravers and painters to advance scientific work. ${ }^{6}$ From 1605 he extended his scientific interests to the study of astronomy, some years before the meeting with Galileo Galilei. Cesi knew the works of Kepler and Tycho Brahe, and supported the theories of Brahe regarding the permeability of the celestial spheres, demonstrated by the appearance and disappearance of comets. ${ }^{7}$ In 1605 he decided to publish, at the expense of the Accademia dei Lincei, the De nova stella disputatio. by Johannes van Heeck, one of the founders of the Academia.

Federico Cesi was born in Rome on 26 February 1585, the son of Marquis Federico and Olimpia Orsini. ${ }^{8}$ The family moved from Umbria to Rome in the fifteenth century and acquired significant positions at the papal court: the family would in due course be rewarded with the appointment of five of their number as cardinals. Federico was the Prince of S. Angelo and S. Polo from 1613 and the second Duke of Acquasparta in June 1630, on the death of his father. He died only a month later in Acquasparta (Umbria) on 1 August 1630.

At the age of eighteen, on 17 August 1603, Federico Cesi became the founder of the Accademia dei Lincei, along with the Dutch physician Joannes van Heeck, his teacher of Botany, the mathematician Francesco Stelluti, and the scholar Anastasio de Filiis. Between 1604 and 1606 the Holy Office tried Joannes van Heeck for heresy, and Federico's father took the opportunity to send him away from Rome and to force his son to suspend his academic activities for a few years. ${ }^{9}$ His

5 Luigi Guerrini, I trattati naturalistici di Federico Cesi (Roma: Accademia Nazionale dei Lincei, 2006). David Freedberg, The eye of the lynx. Galileo, his friends and the beginnings of modern natural history (Chicago-London: The University of Chicago press, 2002).

6 Giuseppe Olmi, Osservazione della natura e raffigurazione in Ulisse Aldrovandi (1522-1605), in Giuseppe Olmi, L'inventario del mondo. Catalogazione della natura e luoghi del sapere nella prima età moderna (Bologna: Il Mulino, 1992), pp. 21-117, in particular pp. 21-6o.

7 Saverio Ricci, ILincei e l'esperienza italiana, in Storia della scienza, vol. v: La rivoluzione scientifica (Roma: Istituto dell'Enciclopedia Italiana, 2002), pp. 100-107. Previously, Saverio Ricci published «Una filosofica milizia». Tre studî sull'Accademia dei Lincei, (Udine: Campanotto, 1994).

8 A biography in Giuseppe Gabrieli, 'Federico Cesi Linceo', Nuova Antologia, s. 7, 272 (1930), pp. 353-369.

9 Saverio Ricci, Il caso Heckius, in I primi Lincei e il Sant'Uffizio: questioni di scienza e di fede (Roma: Bardi, 2005), pp. 207-234. 
academic work resumed in Rome in 1609; Galileo Galilei was enrolled in the Accademia in 1611 .

Federico Cesi started to assemble his library in the family building in via della Maschera d'oro in Rome (near via dei Coronari) between 1603 and 1612. It was intended for his personal use and that of the Lincei. We can follow the activity of Cesi as book collector in his correspondence, published by the librarian of the Lincei Academy Giuseppe Gabrieli in the early twentieth century (1930-1940). ${ }^{10}$ From the letters written to Johannes van Heeck, who was traveling in Europe and especially to Prague, we learn that Cesi sent him money to buy rare books and manuscripts on alchemy, secreta (Secrets of Nature) and natural sciences. In the first decade of the seventeenth century, alchemical studies were an area of particular interest at the court of Rudolph II in Prague. The books collected in Cesi's library had an oval stamp with the image of a linx facing to the left, and the inscription:

\section{EXBIBLIOTH[eca] LYNCAEA FEDERICI CAESII L[ynceorum] P[rincipis] MARCH[ionis] MONT[is] CAEL[ii] II.}

The German physician Johannes Faber (Johannes Schmidt), ${ }^{11}$ Chancellor and Secretary of the Academy from 1611, who died just a year before Cesi, bequeathed to the Academy his manuscripts relating to scientific matter. Cesi also bought 113 printed books from his library, Cassiano Dal Pozzo acquired 154, and Gabriel

10 Giuseppe Gabrieli, 'Il Carteggio linceo della vecchia Accademia di Federico Cesi (16031630). Parte prima (anni 1603-16o9)', Atti della Reale Accademia Nazionale dei Lincei. 1938. Serie sesta. Memorie della classe di Scienze Morali, storiche e filologiche, vol. vII (Roma: Bardi, 1938), pp. 1-120; 'Parte seconda (anni 1610-1624) Sezione I (anni 1610-1615)', Memorie della R. Accademia Nazionale dei Lincei. Classe di Scienze morali, storiche e filologiche. Serie VI. Volume VII. Fascicolo II (Roma: Bardi, 1939), pp. 123-535; 'Parte seconda (anni 16101624) Sezione II (anni 1616-1624)' Memorie della R. Accademia Nazionale dei Lincei. Classe di Scienze morali, storiche e filologiche. Serie vi. Volume viI. Fascicolo III, (Roma: Bardi, 1941), pp. 538-993; 'Parte III ed ultima (anni 1625-1630). Indici', Memorie della R. Accademia Nazionale dei Lincei. Classe di Scienze morali, storiche e filologiche. Serie VI. Volume viI. Fascicolo Iv, (Roma: Bardi. 1942), pp. 999-1446.

11 Johannes Faber (Schmidt) (Bamberg 1574 - Rome 1629), arrived in Rome to improve his scientific studies, welcomed by Christoph Schlüssel (Clavius), professor of Mathematics at the Roman College. He became assistant physician at the S. Spirito in Sassia hospital, and in 1600 professor In simplicibus medicamentis and lecturer of Anatomy at the Sapienza in Rome, after the death of Andrea Bacci, and also director of the botanical garden of the Pope. He was then enrolled at the Accademia dei Lincei in 1611 and became Chancellor and Secretary. 
Naudé, librarian of the Cardinal Giovanni Francesco Guidi di Bagno in Rome, bought 12 books. ${ }^{12}$

Cesi married Artemisia Colonna in 1614 and they lived in the palace located in Acquasparta, near Terni (Umbria), where he also set up his scientific studio. Tragically, Artemisia died two years later, in the aftermath of the premature birth of twins. From 1618 to 1624 Cesi lived in Acquasparta with his second wife Isabella Salviati, the sister of the mathematician Filippo Salviati, Galileo's friend. In his absence the management of the Academy in Rome passed increasingly into the hands of Virginio Cesarini, Master of Chamber of Urban VIII and linceo since 1618. Cesi composed almost all his significant works in Acquasparta, including the Speculum rationis, Frontispicia and Caelispicium; it was here, too, that he prepared the Tesoro messicano for the press. As we can see from the Carteggio linceo, Cesi frequently asked Faber to buy the best editions of the works he needed for his researches in Rome, and to send them to Acquasparta. For instance, we read he required a copy of Matthias de l'Obel's Icones to classify plants in his scientific work:

I am preparing the classification plan of each type of plants, which could constitute a part of my Specchio della Ragione and Theatro della natura, and I think I am almost ready [...]. To have help in collocation and organization of plants, I would need two volumes of Icones by Matthias de L'Obel [...]. So, I beg you to let me have the two unbound volumes; to buy them my trustee Benedetti will give you the money; I beg you to help me as soon as possible and, please, to send me the best existing edition. ${ }^{13}$

12 Gabriella Miggiano, 'Johannes Faber e la sua biblioteca: vecchi e nuovi documenti', Il Bibliotecario, s. III, 1-2 (2010), pp. 115-171; 3 (2010), pp. 45-123; 1-2 (2011), pp. 25-96. Gabriella Miggiano, "Libri prohibiti": qualche appunto dalle carte diJohannes Faber Lynceus Bambergensis, in Maria Teresa Biagetti (ed.), L'organizzazione del sapere. Studi in onore di Alfredo Serrai (Milano: Sylvestre Bonnard, 2004), pp. 245-273. Gabriella Miggiano. Fra politica e scienza: la biblioteca di Johannes Faber Linceo, in Fiammetta Sabba (ed.), Le biblioteche private come paradigma bibliografico (Roma: Bulzoni, 2008), pp. 107-153.

'Mi trovo in quel gran caos della Plantaria distributione metodica, e mi pare quasi haverlo totalmente superato, che sarà una buona parte per il mio Specchio della Ragione e Theatro della Natura [...] ma per più comodo nel locare e ordinare per il fine di questa gran Plantamentatione, haverei di bisogno di doi volumi delle Icones Lobelliane...; prego dunque V.S. a procurarmi a tal effetto doi libri sciolti, che per comprarli ad ogni suo cenno il Benedetti mio ministro le sborserà il denaro che bisognerà; e la prego in ciò favorirmi quanto prima, e che li libri siano compiti della miglior editione che possa haversi.' Letter to Johannes Faber, from Acquasparta, 19 November 1622. Carteggio linceo (1941), letter no. 643 , pp. $77^{8-779}$. 


\section{The Dispersal of the Library}

The library of Federico Cesi was situated in the ducal palace in Acquasparta on the first floor, in a large room, 11 meters in length, facing onto the courtyard.14 As we can see from a letter from Cesi to Faber, it was particularly well-stocked with medical works: "Di medicina V. S. sa che io ho libri esquisiti e molti".15 Precise information about the library in the Acquasparta palace can be found in documents of the Cesi Archive, since merged into the Massimo d'Aracoeli family archive. Since 1996 these papers have been in the Rome State archive. ${ }^{16}$ Particularly important are the documents drawn up between 14 and 21 August 1630, immediately after Cesi's death, concerning the inheritance of Isabella Salviati on behalf of her underage daughters. A folder contains an inventory drawn up by the notary Teodoro Peregrini from Monte Castello, detailing goods, possessions in the Acquasparta area and furnishings in the palace. One paper described the manner in which the library had been classified: 33 divisions containing manuscripts, printed books, letters and papers by the Academy, together with 4 shelves dedicated to Medicine (see table 18.1). The division into 33 classes coincides almost exactly with the boxes of books described in the inventory contained in Ms. A. L. XXxiI (see table 18.2).

The library, which probably contained about 3,000 items, was now broken up. After Cesi's death on 1 August 1630, Isabella Salviati with the assistance of Francesco Stelluti, close collaborator of Cesi and the manager of the Accademia, sold the main part of the library to Cassiano Dal Pozzo, a scholar and book

14 The description is offered by Pietro Capparoni, La sala del palazzo Cesi in Acquasparta dove furono tenute le prime adunanze dell'Accademia dei Lincei e le sue iscrizioni, in Atti del $7^{\circ}$ Congresso nazionale della Società italiana di Storia critica delle Scienze Mediche e Naturali (Roma 1912) (Grottaferrata: Tipografia Italo-Orientale S. Nilo, 1914), pp. 3-14. Capparoni uses information from a manuscript of 1759 , kept in the archive of the collegiate church of S. Cecilia in Acquasparta.

15 Letter to Johannes Faber, from Acquasparta, March-April 1624. Carteggio linceo, 1941, pp. 859-86o, letter no. 728 .

16 The archive of the Cesi family, which Baldassarre Odescalchi consulted, was transferred from the Albani family to the Massimo family and at the end to the Colonna family. It is described briefly in the paper by Enrica Schettini Piazza, 'Spigolando nell'Archivio Cesi', in Andrea Battistini et al. (eds.), All'origine della scienza moderna: Federico Cesi e l'Accademia dei Lincei (Bologna: Il Mulino, 2007), pp. 467-479. Schettini reports on the composition of the Cesi archive, and of its structure (envelopes 142-287). She also indicates the presence of significant documents for the reconstruction of the family situation and assets of Federico Cesi, and in particular the inventory drawn up after his death. However, she does not transcribe or analyze the documents. 
TABle 18.1 Archivio di Stato di Roma. Archivio Massimo. Busta 237 - Eredità Cesi. Inuentario della Salviati, f. 18 rv.

A manuscritti

B filosophia scolastica

C fisica scholastica e metafisica

D Secreti e Medicina

E Astronomici e Matematici

F Medicina e Naturalisti

G Medicina e Piante d'Herbe

H Medicina

I Matematici

K Libri varij

L Historici

M Eruditi

N Morali

O Poeti

P Grammatici

Q Libri varij

R Grammatici

S Eruditi

T Historici

V libri varij

$\mathrm{X}$ Cosmografia et alii libri varij

$\mathrm{Z}$ fighure di dame diuerse

AA lettere de Lincei e loro libri stampati

BB manuscritti con tre scatole con instr(ument)i matematici d ottone

CC manuscritti diuersi

DD libri stampati di diuerse materie

EE libri stampati di diuerse materie

ff libri di diuerse materie

GG libri stampati di diuerse materie

HH libri stampati di diuerse materie

II lettere di diuersi

KK Scritture diuerse

MM Scritture diuerse 
TABLE 18.2 Comparison between the paper describing the divisions of the library in Acquasparta and the disciplinary divisions presented in the A. L.XXXII.

Inventario Peregrini 1630 (Acquasparta) ${ }^{17}$

A Manuscritti

B Filosophia scolastica

C Fisica scholastica e metafisica

D Secreti e Medicina

E Astronomici e Matematici

F Medicina e Naturalisti

G Medicina e Piante d' Herbe

H Medicina

I Matematici

K Libri varij

L Historici

M Eruditi

N Morali

O Poeti

P Grammatici

Q Libri varij

R Grammatici

S Eruditi

T Historici

V Libri varij

X Cosmografia et alii libri varij

Z Fighure di dame diuerse

DD Libri stampati di diuerse materie

EE Libri stampati di diuerse materie

ff Libri di diuerse materie

GG Libri stampati di diuerse materie

HH Libri stampati di diuerse materie
Archivio Linceo XXXII ${ }^{18}$

\author{
Cassa B Fisici e Teologici \\ Cassa C Fisici e Teologici \\ Cassa D Secreti naturali \\ Cassa E Matematica \\ Cassa F Naturali e medicinali \\ Cassa G Medicina e piante \\ Cassa H Libri di Medicina \\ Cassa I Matematica \\ Cassa K Libri vari \\ Cassa L Historici \\ Cassa M Eruditi \\ Cassa N Morali et Historici \\ Cassa O Poeti \\ Cassa P Grammatici \\ Cassa Q Libri vari \\ Cassa R Grammatici \\ Cassa S Eruditi \\ Cassa T Historici \\ Cassa V Libri vari \\ Cassa X Libri vari \\ Cassa Z Libri vari \\ Cassa cc Libri vari \\ Prima Scantia in $\mathrm{f}$. \\ Diversi \\ Cassa GG Libri vari \\ Libri sciolti \\ Scantia 2. in $8^{\circ}$
}

17 Inventory drawn up by the notary Teodoro Peregrini. Archivio di Stato, Roma. Archivio Massimo. Busta 237 - Eredità Cesi. Inventario della Salviati, f. 18rv. In this table, the list of divisions is not complete. See the complete list in table 18.1

18 The disciplinary divisions shown in the A. L. Xxxı are here presented not in the original order, but in alphabetical order, to make evident the connection with the Inventario by Teodoro Peregrini. 
II Lettere di diuersi

KK Scritture diuerse

MM Scritture diuerse

collector enrolled in the Accademia dei Lincei in 1622. Cardinal Francesco Barberini bought many dozens of books. The library was sold to Dal Pozzo on 21 January 1633; he combined it with his own library in via dei Chiavàri in Rome, near the basilica of S. Andrea della Valle. ${ }^{19}$

The last heir of Dal Pozzo, Cosimo Antonio Dal Pozzo, sold the manuscripts in 1703 and the printed books of Cassiano's library to the archbishop Zacagni, principal keeper of the Vatican Apostolic Library, but he could not complete the purchase. The same happened to his successor, Carlo Maielli, who in 1714 was obliged to allow Cardinal Alessandro Albani, nephew of Pope Clement XI and a great collector of works of fine art, to purchase the collection. Alessandro Albani assigned the library to his family with a formal act, and transferred it first to the Quirinale, and then, in 1720, to the Albani palace. For this reason the collection, which also incorporated the extraordinary library of Federico Cesi, was not merged into the Vatican Apostolic Library. ${ }^{20}$

In 1798 the French revolutionaries confiscated the Albani property and the library: probably because Giovanni Francesco Albani, nephew of Cardinal Alessandro, and dean of the Sacred College, was head of the anti-French party and supported the armed resistance against the French army. The French

19 Regarding the library of Cassiano Dal Pozzo, see Ada Alessandrini, Cimeli lincei a Montpellier (Roma: Accademia Nazionale dei Lincei, 1978). Partial reconstruction of the Dal Pozzo library, based on Manuscript XL of the Archivio Linceo owned by the Accademia of Lincei library, is in the paper by Silvia De Renzi, 'Contributo per una ricostruzione della biblioteca privata di Cassiano Dal Pozzo,' in Eugenio Canone (ed.), Bibliothecae selectae. Da Cusano a Leopardi (Firenze: Olschki, 1993), pp. 139-170. Also interesting is the exibition, whose catalogue has been printed: Francesco Solinas (ed.), I segreti di un collezionista. Le straordinarie raccolte di Cassiano Dal Pozzo, (Roma: De Luca, 200o).

20 The detailed account of the events in Alessandrini, Cimeli lincei a Montpellier. The paper by Enrica Schettini Piazza, 'Più "studio" che "passatempo": la libraria di Federico Cesi e le sue peregrinazioni,' in Vincenzo Pirro (ed.), Federico Cesi e i primi Lincei in Umbria. Atti del Convegno di studi nel IV centenario della fondazione dell'Accademia dei Lincei. Terni, 24-25 ottobre 2003 (Terni: Thyrus, 2005), pp. 129-154, is also helpful. 
revolutionaries removed the manuscripts and transported them to France, where the Napoleonic government acquired them in 1804. Many manuscripts owned by Cesi are in fact now in the library of the École de Médecine in Montpellier. The Albani family later bought back part of the printed books.

When the Albani family died out in $185^{2}$, their heirs, the Castelbarco and Guidi di Bagno Chigi, decided to sell the bulk of the printed books through two public auctions in 1857 and in 1858; 85 manuscripts were sold to Baldassarre Boncompagni and a small number to Duke Massimo, who later gave them to the Accademia dei nuovi Lincei. Approximately 1,70o books, manuscripts and printed books were bought by the Imperial Library of Berlin on behalf of the Ministries of Finance and Education of Prussia, a sale facilitated by delegates of the Castelbarco and Guidi di Bagno Chigi families, and the assistance of Theodor Mommsen. Unfortunately, the ship with the cargo of 12 crates of books was wrecked in the Atlantic Ocean before arriving in the port of Hamburg, and the books disappeared. Thus some of the books that belonged to Cesi were lost at sea, and some were sold and dispersed in different collections. In the circumstances it will never be possible to achieve more than partial reconstruction of the original library. Anna Capecchi has identified 124 editions of works on Natural history; Enrica Schettini has identified 150 works of literature and erudition and provided information about the surviving copies in various libraries, based on the evidence offered by the copies with the stamp of Federico Cesi. ${ }^{21}$

A bibliographical reconstruction of the extraordinary collection of Federico Cesi can however be attempted on the basis of two manuscript inventories of the seventeenth century owned by the Accademia dei Lincei. ${ }^{22}$ Ms. A. L. XXXII, which Paolo Volpicelli gave to the Academy in 1866, is almost surely the oldest inventory, drawn up on behalf of the family after Cesi's death. It consists of 107 leaves containing a list of the houses, other properties, and land in the Acquasparta area, together with an inventory of 23 shelves, 2 little shelves

21 Anna Capecchi, 'Per la ricostruzione di una biblioteca seicentesca: i libri di storia naturale di Federico Cesi Lynceorum Princeps', Atti della Accademia Nazionale dei Lincei. Serie ottava. Rendiconti. Classe di Scienze morali, storiche, filologiche. vol. XLI, 5-6 (1986), pp. 145-164; Schettini Piazza, 'Più "studio" che "passatempo": la libraria di Federico Cesi'. The first reconstruction in Giuseppe Gabrieli, 'La prima biblioteca lincea o libreria di Federico Cesi', Rendiconti della R. Accademia Nazionale dei Lincei. Classe di Scienze morali, storiche e filologiche, s. VI, vol. XIV, (1938), pp. 606-628.

22 The complete reconstruction of the library in Maria Teresa Biagetti, La biblioteca di Federico Cesi (Roma: Bulzoni, 2008). 
and loose books. It mentions 1,978 items (bibliographical units), providing rough descriptions of works and authors, and is full of inaccuracies. The disciplinary classes are almost exactly those shown in the chart of Cesi family Archive (33 classes of the library in Acquasparta palace, Inventory of the notary Teodoro Peregrini) (see Table 18.2). Ms. A. L. XIII consists of 333 leaves with a series of book lists, often overlapping, along with letters and charts not belonging to the library. One of the most useful lists in this group provides more accurate descriptions of the books realized during the sale by the German bookseller Hermann Scheuss. Here there are many descriptions of law books, not present in Ms XXXII. This list also often includes the prices of the books (scudi and giulii).

We have evidence regarding a portion of the manuscripts from the library through the work by Martin Fogel (1634-1675), theologian, physician and naturalist, who received bibliographical citations, news, letters and documentation about the Accademia dei Lincei from Antonio Magliabechi and Carlo Antonio Dal Pozzo, brother of Cassiano. Giuseppe Gabrieli published an inventory of 146 manuscripts owned by Cesi, among which we find some manuscripts by Giambattista Della Porta, a considerable number of manuscripts of alchemic and spagyric Medicine, along with manuscript works by Johannes van Heeck, Fabio Colonna, Theophilus Müller and Vincenzo Mirabella. ${ }^{23}$

I decided to transcribe Ms XxxiI because it is almost certainly the oldest. We know this because almost all the items listed in the manuscript XXXII date before 1630 with only three 1630 editions. Ms A. L. XIII has eight 1630 editions, three editions printed in 1631, two in 1632 and two in 1633. In addition, the disciplinary divisions of the library in the Acquasparta palace, as is shown by the chart of the Cesi family archive, overlap almost completely with the disciplinary divisions described in the manuscript A. L. XXXII, with almost the same alphabetical letters. This can be seen in table 18.2.

I decided to transcribe Ms. A. L. XXXII (1,978 items) in its entirety and to draw from the lists in Ms. A. L. XIII only the items not already present in the Ms. A. L. XXXII. The bibliographic items contained in Ms. A. L. XXXII, transcribed in full, have been used as a template for comparing the works and editions in all the lists provided by Ms. A. L. XIII. Through a precise comparison of

23 Giuseppe Gabrieli, 'Le "Schede Fogheliane" e la storiografia della prima Accademia Lincea'. Rendiconti della R. Accademia Nazionale dei Lincei. Classe di Scienze Morali, storiche e filologiche. s. 6, vol. Xv. (Roma: Bardi, 1939), pp. 140-167, reprinted in Giuseppe Gabrieli, Contributi alla storia dell'Accademia dei Lincei (Roma: Accademia Nazionale dei Lincei, 1989), pp. 273-296. 
the items in the two manuscripts, I have derived about 1,0oo new bibliographic items from Ms. A. L. XIII, in particular legal books and works in Spanish and French. In total, there are now 2,972 bibliographic items. I have identified nearly all authors, works and editions where this was possible; a considerable portion of the editions have been described by autopsy. In addition, I have integrated data contained in Ms A. L. XXXII with data contained in Ms A. L. XIII, whenever this was more complete: for example, when this provided the name of an editor or a publisher, or a date of issue, missing in Ms. XXXII, or date of issue that, unlike that of the Ms. XxxII, had an exact match.

\section{Scientific Configuration of the Cesi's Collection}

Cesi's library was an extraordinary private library and an encyclopedic collection. It represents the interests of a scientist of great importance in the first half of the seventeenth century, who was involved in scientific discoveries of crucial importance. The library is evidence of the profound scientific enquiries of the historical period in which it was collected: the Copernican revolution, the emergence of the Baconian sciences and the revolution of spagyric medicine.

Cesi was mainly a botanist and a zoologist: in particular, he was interested in plant reproduction. It is not surprising, therefore, to find a part of the library devoted to botany: classical authors as Gaius Plinius Secundus (Pliny the Elder) and Theophrastus, but also works by Pietro Andrea Mattioli (1500-1577), physician and naturalist, and by Andrea Cesalpino (c. 1524-1603), physician, botanist, and professor of Medicine at the Sapienza University of Rome. There are six works by Ulisse Aldrovandi (1522-1605), physician and naturalist of Bologna; eight works by Caspar Bauhin, (1560-1624), botanist and professor of Medicine at Basel, contemporary of Federico Cesi. Ulisse Aldrovandi had a great influence on Cesi's scientific method. Cesi described plants and produced manuscripts with botanic illustrations (for example fungi and algae) following the technique established by Aldrovandi, who in the sixteenth century had made scientific representation of plants and animals using many engravers and painters. Compared to the illustrations made by Aldrovandi, however, Cesi's were original, advanced and innovative, because he had used a microscope since 1625. Johannes Faber had called that tool 'microscopio' and he had reported to Cesi in a letter dated 13 April 1625: "questo novo ochiale di vedere le cose minute et lo chiamo microscopio, veda V. Ecc. ${ }^{\text {aa }}$ se gli piace". ${ }^{24}$

24 Letter to Federico Cesi. Carteggio linceo, 1942, letter no. 841, pp. 1038-1039. 
The private library of Cesi is most remarkable for the massive presence of medical works of Paracelsan orientation. The Swiss physician Paracelsus (Philipp Theophrast Bombast von Hohenheim) (1493-1541) was especially influential in the use of Alchemy in Medicine. It is known that the Lincei in the early years, in particular the Germans, Johannes Faber, Johannes Schreck and Theophilus Müller, were interested in the diffusion of alchemical studies and thus of medical works of Paracelsan orientation. ${ }^{25}$ Cesi owned works by Paracelsus, including Chirurgia minoris, and Metamorphosis. He also owned works by prominent supporters of the spagyric medicine, such as Joseph Duchesne also known as Quercetanus, including his Pharmacopea Dogmaticorum restituta and Liber de priscorum philosophorum verae medicinae materia; the Basilica chymica of Oswald Croll; some works by Philip Muller, including Miracula chymica and by Bernard Penot (a collection of chemical remedies of Paracelsian orientation). In addition there were works by followers of Paracelsus, such as Daniel Sennert (1572-1637), physician and professor at Wittenberg and Jean Béguin (1550-1620); six works by Ramón Lull; many works by Della Porta, including De distillatione. Cesi owned alchemical works by Italian authors: Giovanni Bracesco, Leonardo Fioravanti, Giovan Battista Nazari, and the Corpus alchemicus (editions 1545 and 1598) attributed to Geber (Jābir ibn Hayyān). The most remarkable portion of the library consists of the works by the German physician Libavius, who used alchemy but rejected extreme positions, such as the occult, including his Rerum chymicarum and Alchymia (1597 and 1606 ). ${ }^{26}$ It should also be said that Cesi also owned works by Galen and by the opponents of Paracelsus, such as Jean Riolan (1580-1657), an active participant in the disputes in Paris between the supporters of Galen and the followers of Paracelsus.

In its orientation the library of Federico Cesi shows a particular similarity with the chemical collection that Antonio dei Medici (1576-1621), the illegitimate son of Francesco I and Bianca Cappello, had gathered at the Casino di S. Marco in Florence in the early seventeenth century. That library also contained many of the works by Paracelsus, by his European supporters and by his detractors. ${ }^{27}$

25 Saverio Ricci, 'Paracelso superstitione nudatus. I primi Lincei e l'alchimia,' in Ricci, «Una filosofica milizia», pp. 35-57; Paolo Galluzzi, Motivi paracelsiani nella Toscana di Cosimo II e di Don Antonio dei Medici:Alchimia, Medicina, «Chimica» e riforma del sapere, in Scienze credenze occulte livelli di cultura. Convegno Internazionale di studi (Firenze, 26-3o giugno 1980) (Firenze: Olschki, 1982), pp. 31-62.

26 Andreas Libavius (Libau) (c. 1546-1616).

27 The inventory of the library of Antonio dei Medici has been studied by Galluzzi, Motivi paracelsiani nella Toscana di Cosimo II e di Don Antonio dei Medici. 
A significant portion of the library of Federico Cesi was devoted to Secreta naturae. Alchemy and astrological medicine had been a special point of interest for the Hermetic-magic tradition. Throughout the Renaissance period, that interest was expressed in the production of works that we can ascribe to the genre of Natural Secrets. The library contains about 150 works of popular science, medicinal remedies, results of empirical experimentation, and treatises of practical alchemy. ${ }^{28}$ The Secreta naturae developed in the Renaissance period and flourished in the seventeenth century. Its success can be ascribed to new experimental empirical sciences based on observation, namely Chemistry, studies of magnetism and electricity. During the seventeenth century, the study of these empirical sciences, which Thomas Kuhn defined as 'Baconian sciences', took its place along with the classical physical sciences, such as mathematics, astronomy, and optics. ${ }^{29}$ The genre of Natural Secrets was also connected to the Hermetic tradition. Rather than through the philosophical and religious tradition of the Corpus Hermeticum, the connection was through works of Astronomy, Alchemy, Natural sciences and Magic of the disciples of Hermes Trismegistus (Liber Hermetis Trismegisti for the Astrology, and Kyranis ermetica for Natural sciences and Medicine). ${ }^{30}$

The collection of Federico Cesi has been analysed using the bibliography of books of Natural Secrets by John Ferguson and the studies of Alfredo Serrai. ${ }^{31}$ I found a massive presence of the most representative authors of the genre of Natural Secrets, such as Alessio Piemontese, Giambattista Della Porta and Antoine Mizauld, French physician and hermetic-neoplatonist. There is a considerable presence of Italian authors of Medical Secrets, such as Gabriele Falloppio (15231562), physician and professor of Anatomy, Pietro Bairo (1468-1558), physician of

28 They are about 130 in the 'Cassa D Secreti naturali', in the Ms. A. L. xxxiI.

29 Thomas S. Kuhn, 'Mathematical vs. Experimental Tradition in the Development of Physical Science', Journal of Interdisciplinary History, 7, 1 (1976), pp. 1-31.

30 André Jean Festugière, La révélation d'Hermès Trismégiste, 2. ed., ([Paris]: J. Gabalda, 3 vol. 1949-1953). (Reprint Paris: Societé d'édition Les belles lettres, 1981). In vol. I, L’Astrologie et les sciences occultes. 2. ed. ([Paris], J. Gabalda, 1950), (reprint Paris: Societé d'édition Les belles lettres, 1981), Festugière analyzes the tradition of the 'Hermétisme populaire', and sudies the Hermetic works of Astrology, Alchemy, Magic, astrological Botany, Therapeutics, based on the correspondence between the natural elements, and of Iatromathematics (astrological medicine).

31 John Ferguson, Bibliographical notes on histories of inventions and books of secrets (London: The Holland Press, 1959) (1981 reprint). Alfredo Serrai, Storia della Bibliografia. I. Maria Cochetti (ed.), Bibliografia e Cabala. Le Enciclopedie rinascimentali (I) (Roma: Bulzoni, 1988), pp. 338-395. Serrai considers the 'Libri di Segreti' as 'technological encyclopedias' within the wide discussion of the encyclopedias of the Renaissance. 
Carlo II Duke of Savoy, and Giovanni Battista Zapata. Worthy of note is the presence of the collection of medical and natural contents by the Dutch Levinius Lemnius, of the work of Chemistry applied to Pharmacology by Conrad Gesner, Thesaurus de remediis secretis, and the encyclopedia of Natural Philosophy by Girolamo Cardano, De subtilitate.

Less substantial from the quantitative viewpoint, but very meaningful for the connection with the ongoing scientific revolution, was the collection of works of Astronomy:Almagestum by Tolomeo, works by Kepler and Copernicus, works by Galileo published by the Lincei Academy (Il Saggiatore, 1623). Additionally, there are works by the disciples of Galileo, such as Benedetto Castelli and Nicolò Antonio Stelliola, and by the opponents of Galileo, such as Christoph Scheiner and Orazio Grassi, both professors of Mathematics at the Roman College.

The library also included works on the organization of the sciences and of technical support for the memory, such as the works by Giulio Camillo, Cornelius Gemma, Pierre Grégoire, and the organization of knowledge using 'loci communes', such as the works by Jean Tixier, Polyanthea by Domenico Nani Mirabelli, and Silva by Pedro Mejia. There were also classics of Latin literature in several different editions and commentaries, works of literature, Italian, French and Spanish, the works of ancient philosophers and modern scholars, and a substantial core of legal works.

Finally, it is important to emphasize that Federico Cesi's collection included a considerable number of forbidden books. These were identified using the Index by Francesco Capiferro Maddaleni (1632), which includes the Index of 1596 and is enriched by references to edicts and decrees of prohibition issued after the Tridentine and Clementine Indices. ${ }^{32}$ It provides an overview of the prohibitions in force on the date of the sale of the library of Cesi. Authors in the cumulative Index by Capiferro and owned by Federico Cesi include authors whose works were entirely included in Indexes of prohibition: Conrad Gesner, Heirich Cornelius Agrippa von Nettesheim, Kaspar Schwenckfeld, Georg Fabricius, Gilbert Cousin, Joachim Camerarius, Johann Lonicer, Leonard Fuchs, Otto Brunfels, Pietro Ramo, Sébastien Châteillon, Valentinus Erythraeus, Paracelso, Johannes Sleidanus. Among authors in the second class, for whom only individual works were forbidden, we find Johannes Reuchlin, Bernard Peinot, Antoine Mizauld (donec corrigatur), Robert Fludd, Andreas Libavius, Theodor Zwinger (nisi corrigatur), Nicolaus Copernicus and Giordano Bruno.

Elenchus librorum omnium tum in Tridentino, Clementinoq. Indice, tum in alijs omnibus sacrae Indicis Congreg.nis particularibus Decretis hactenus prohibitorum; ordine uno alphabetico [...] digestus. (Rome: ex Stamperia Camerale, 1623). 